\title{
Afrahat, Mowa XX: O trosce o biednych \\ (Demonstratio XX: De sustentatione egenorum, PSyr 1, 893-930)

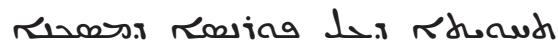

\section{Wstęp}

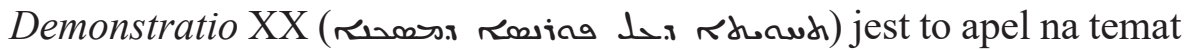
dobroczynności skierowany do wszystkich chrześcijan Kościoła w Persji a szczególnie do członków społeczności „synów przymierza”. Afrahat pragnie zachęcić słuchaczy do podjęcia dzieła caritas christiana i umocnić tych chrześcijan, którzy już wspierają ubogich. Motywy podjęcia tematu wyjaśnione zostały dopiero w ostatnim punkcie De sustentatione egenorum. Autor konsekwentnie, świadomie i celowo stylizuje formę swojego przekazu za pomocą figury retorycznej „mój przyjacielu” (טרירת): „Napisałem

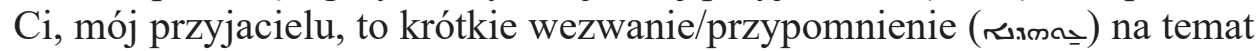
darów dla ubogich (كمصنrzekonaj i zachęć tych, którzy dają, aby rozsiewali przed sobą zasiew życia, zgodnie z tym, co jest napisane: Ucz prawego, a zwiększy swą wiedzę (por. Prz 9,9). Wszystkich, którzy miłują

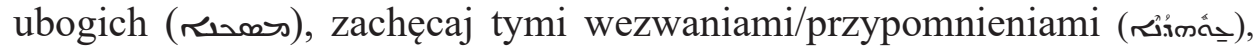
abyś i ty miał udział w ich trudzie" ${ }^{1}$. Trudno znaleźć uzasadnienie umieszczenia tej mowy pod koniec całości dzieła. Analizując zawartość treściową tej biblijno-dydaktycznej instrukcji, należy uwzględnić kontekst społeczno-religijny, w jakim znalazł się Kościół w połowie IV wieku w Imperium Perskim. Chrześcijanie musieli zmagać się z terrorem prześladowań inicjowanych na dworze szachinszacha Szapura II i stymulowanych przez kapłanów państwowego zoroastryzmu. Drugim równie niebezpiecznym zagrożeniem dla chrześcijan perskich, w większości nawróconych Żydów, było silne oddziaływanie judaizmu. Religia przodków zarówno na płaszczyźnie regulacji formalizmu kultycznego, jak i umiejętności adaptacji w różnych

1 Między innymi: Aphraates, Demonstratio 20, 19, PSyr 1, 929, 1-10; Aphraates, Demonstratio 19: Adversus Iudaeos qui dicunt se denuo congregatum iri, PSyr 1, 845-892; Aphraates, Demonstratio 17: De Christo Dei Filio, PSyr 1, 785-816. 
środowiskach życia diaspory żydowskiej stanowiła atrakcyjną konkurencję dla chrześcijańskich gmin ${ }^{2}$. Zdaniem Adama H. Beckera De sustentatione egenorum wyraźnie świadczy o trudnej sytuacji chrześcijan babilońskich, którzy w czasie prześladowań Szapura II, nie rozumiejąc istotnych różnic między chrześcijaństwem a judaizmem, odwiedzali synagogi i korzystali z dobroczynności Żydów3 . Sytuacja na terenie Mezopotamii, w której pod panowaniem Perskiego Imperium wyznawcy obu religii żyli jako mniejszości religijne, ukazuje złożoność relacji między Żydami i chrześcijanami W starożytności ${ }^{4}$.

Swojego słuchacza Pers traktuje jak ucznia, ale rzadziej (cztery razy) niż w Demonstratio XIX: Przeciwko Żydom, którzy mówia, że na nowo zostana zgromadzeni używa zwrotu „zobacz” (sw), zachęcając do skupienia uwagi na przekazywanych dezyderatach ${ }^{5}$. Również o wiele uboższy jest zestaw argumentów stosowanych w polemice z Żydami. Wydaje się, jakby autor celowo powstrzymywał się od bardziej agresywnej formy dyskusji z nauczaniem rabinów babilońskich jak to ma miejsce w innych

2 Por. A.F.J. Klijn, The Influence of Jewish Theology on the Odes of Salomon and the Acts of Thomas, w: Aspects du judéo-christianisme, red. J. Neusner, Paris 1965, s. 167-168. Większość w Kościele babilońsko-mezopotamskim mieli stanowić chrześcijanie pochodzący z pogaństwa. Por. J. Neusner, Aphrahat and Judaism. The ChristianJewish Argument in Fourth-Century Iran, Studia Post-Biblica 19, Leiden 1971, s. 126-127.

3 Por. A.H. Becker, Anti-Judaism and Care of the Poor in Aphrahat's Demonstration 20, JECS 10/3 (2002) s. 305-327; A.H. Becker, Bringing the Heavenly Academy Down to Earth: Approaches to the Imagery of Divine Pedagogy in the East-Syrian Tradition, w: Heavenly Realms and Earthly Realities in Late Antique Religions, red. Ra'anan S. Boustan - A. Yoshiko Reed, Cambridge 2004, s. 174-191.

4 Por. Becker, Bringing the Heavenly Academy Down to Earth, s. 188. Martin Goodmann sugeruje, że relacje między Żydami i chrześcijanami miały istotne znaczenie głównie dla chrześcijan jako ważny faktor w skomplikowanym procesie ich samookreślenia (,part of their self-definition”). Jego zdaniem w późnej starożytności judaizm mógł ignorować stanowisko i zachowanie chrześcijaństwa. Por. The Function of Minim in Early Rabbinic Judaism, w: Geschichte-Tradition-Reflexion, Festschrift für Martin Hengel zum 70 Geburtstag, vol. 1, Judentum, red. P. Schäfer, Tübingen 1996, s. 501-510). Zob. teorię Jamesa Parkesa i wyrażenie, ,the parting of the ways" (The Conflict of the Church and the Synagogue. A Study in the Origins of Antisemitism, London 1934, s. 71-120). Dyskusja z modelem Parkesa, por. A.H. Becker - A.Y. Reed, Introduction. Tradition Models and New Directions, w: The Ways that Never Parted: Jews and Christians in Late Antiquity and the early Middle Ages, red. A.Y. Reed - A.H. Becker, Tübingen 2003, s. 1-34.

5 Por. Aphraates, Demonstratio 20, 4, PSyr 1, 900, 16; 20, 8; PSyr 1, 905, 22; 20, 14; PSyr 1, 913, 15; 20, 17; PSyr 1, 924, 22. Por. Aphraates, Demonstratio 19: Adversus Iudaeos qui dicunt se denuo congregatum iri, PSyr 1, 845-892. 
Demonstrationes drugiej części dzieła (De circumcisione ${ }^{6}$; De paschate ${ }^{7}$; De sabbato ${ }^{8}$; De dictinctione ciborum ${ }^{9}$; De Gentibus quae Loco Populi Suffectae Sunt ${ }^{10}$; De Christo Dei Filio ${ }^{11}$; Adversus Iudaeos de virginitate et sanctitate $^{12}$; De persecutione $\left.{ }^{13}\right)$.

We wszystkich Demonstrationes Perskiego Mędrca tytułowa nazwa mowy „wykład” (rłond) ${ }^{14}$ pełni funkcję pojęcia technicznego, a tutaj znajduje swoje semantyczne rozwinięcie w synonimie ,przy-

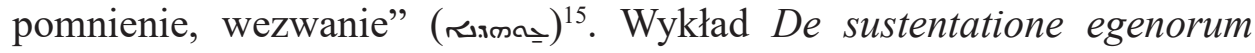

6 Por. Aphraates, Demonstratio 11, Afrahat, O obrzezaniu (Demonstratio XI: De circumcision, Patrologia Syriaca I, 467-504), thumaczenie z języka syryjskiego i komentarz A. Uciecha, SSHT 48/2 (2015) s. 344-356.

7 Por. Aphraates, Demonstratio 12, Afrahat, O święcie Paschy (Demonstratio XII: De paschate, Patrologia Syriaca I, 505-540), tłumaczenie z języka syryjskiego i komentarz A. Uciecha, SSHT 50/1 (2017) s. 5-18.

8 Por. Aphraates, Demonstratio 13, Afrahat, O szabacie (Demonstratio XIII: De sabbato, Patrologia Syriaca I, 541-572), tłumaczenie z języka syryjskiego i komentarz A. Uciecha, VoxP 66 (2016) s. 513-526.

9 Por. Aphraates, Demonstratio 15, A. Uciecha, Afrahat, O pokarmach czystych i nieczystych (Demonstratio XV: De dictinctione ciborum, Patrologia Syriaca I, 728-757), SSHT 51/2 (2018) s. 345-360 (tłumaczenie z języka syryjskiego i komentarz).

10 Por. Aphraates, Demonstratio16, Afrahat, O narodach, które zastapity naród (Demonstratio XVI: De Gentibus quae Loco Populi Suffectae Sunt, PSyr 1, 760-784), tłumaczenie z języka syryjskiego i komentarz A. Uciecha, VoxP 71 (2019) s. 575-591.

11 Por. Aphraates, Demonstratio 17: De Christo Dei Filio, PSyr 1, 785-816.

12 Por. Aphraates, Demonstratio 18, Afrahat, Przeciw Żydom o dziewictwie i świętości (Demonstratio XVIII: Adversus Iudaeos de virginitate et sanctitate, Patrologia Syriaca 1, 817-844), tłumaczenie z języka syryjskiego i komentarz, VoxP 68 (2017) s. 593-604.

13 Por. Aphraates, Demonstratio 21: De persecutione, PSyr 1, 931-990.

14 Por. A. Uciecha, rłowd (tahwwythā) jako metoda egzegetyczna $w$ pismach Afrahata, perskiego Mędrca, „Biblica et Patristica Thoruniensia” 8/1 (2015) s. 68.

15 r.sm ("memoria' - Prov. X. 7, ,adnotatio"). Por. Thesaurus Syriacus, red. R. Payne Smith, t. 2, Oxonii 1901, s. 2819-20; Lexicon Syriacum, red. C. Brockelmann, Berlin 1895, s. 514: ,admonitio”. Parisot (PSyr 1, 929, 1, 7) thumaczy tutaj „,commenta-

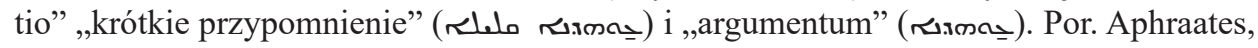

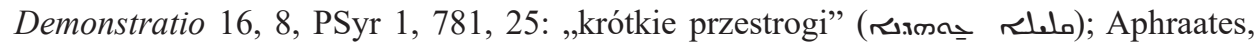

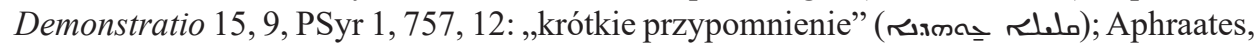

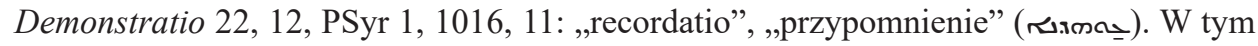
ostatnim przypadku zaproponowane tłumaczenie jest błędne i wymaga korekty: „Nikt tam już nie będzie zniewolony pragnieniem pożądliwym, ani wprowadzony w błąd przez zapomnienie" (Afrahat, O śmierci i czasach ostatecznych (Demonstratio XXII: De morte et novissimis temporibus, PSyr 1, 992-1049), tłumaczenie z języka syryjskiego i komentarz A. Uciecha, VoxP 69 (2018) s. 807). Winno być: „Nikt tam już nie będzie zniewolony 


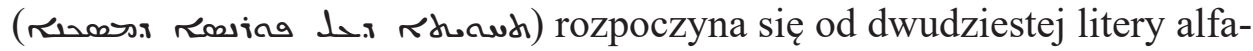

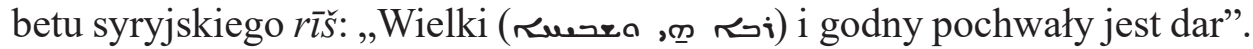
Termin rosina, który Joannes Parisot przetłumaczył jako „sustentatio"16, znaczy 'troska, pomoc, wsparcie'17.

Perski Mędrzec rozpoczyna swój wykład od krótkiej mowy pochwalnej i zachęty do podjęcia troski o biednych. To wstępne elogium składa się z sekwencji czterech cytatów proroka Izajasza wychwalającego troskę o potrzebujących: pomoc biednym jest przejawem roztropności i wyrazem autentycznej pobożności. Afrahat piętnuje postawę zakłamania swoich przeciwników, których nazywa złodziejami. Możliwe, że ta aluzja była jednoznacznie odczytywana w gronie słuchaczy (1). Następnie przywołuje autorytet Mojżesza, który w przepisach Tory wskazywał zasady postępowania wobec biednych (2-3). Przykładem jest również Dawid, który jako pobożny władca w swoich modlitwach i królewskich rozporządzeniach dbał o potrzebujących (4). W dłuższym komentarzu Pers wyjaśnia przypowieści ( ₹łowd) Jezusa o bogaczu, który pragnął jedynie pomnażać swoje dobra (por. Łk 12,13-21), o kryteriach oceny na sądzie ostatecznym (por. Mt 25) i o człowieku bogatym, który za karę trafił po śmierci do szeolu, i Łazarzu, który w nagrodę zasiadł na łonie Abrahama (por. Łk 16,19-31). W krótkich dygresjach autor przypomina o porażce narodu, który nie słuchał Mojżesza oraz proroków i który nie uwierzył zmartwychwstałemu Jezusowi (5-12). W słowach proroków Daniela i Amosa Afrahat znajduje dodatkowy argument za odrzuceniem Żydów jako narodu wybranego (13). W prorockiej wizji różnorodne i bujnie rosnące na pustyni drzewa (Iz 41,17-19) symbolizują chrześcijan („kapłani ludu i święte Przymierze”),

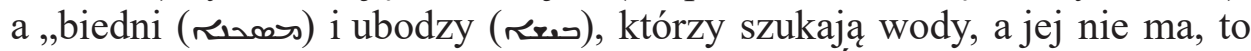
lud, który pochodzi z ludów; woda zaś to nauka Świętych Pism”. Wydaje się, że w tym właśnie punkcie krzyżują się dwie podstawowe linie wyznaczające oś polemicznego dowodzenia Syryjczyka: dyskwalifikacja Żydów i wyniesienie na ich miejsce „ludu pochodzącego z ludów”.

pragnieniem pożądliwym, ani wprowadzony w błąd przez wspominanie”. Inne pojęcia stosowane w terminologii Demonstrationes to między innymi sتلح (PSyr 1, 786, 1). Por. Thesaurus Syriacus, t. 2, s. 2110-2111: تله - 'sermo, verbum, dictum, causa, ratio'; ‘krót-

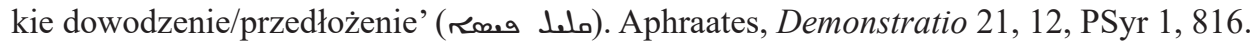
Por. Uciecha, rłowd (tahwaythā) jako metoda egzegetyczna w pismach Afrahata, perskiego Mędrca, s. 66.

16 Por. Aphraatis Sapientis Persae Demonstrationes, PSyr 1, Paris 1894, 893-894.

17 Por. Thesaurus Syriacus, t. 2, s. 3270-3271: ,administratio, sustentatio, gubernatio, providentia"; Lexicon Syriacum, s. 599. 
Idea substytucji koresponduje z czynnikiem subordynacji przepisom Prawa, w tym Bożym nakazom okazania pomocy potrzebującym. Skutkiem odrzucenia tej dyscypliny przez Żydów była utrata statusu narodu wybranego według Bożej obietnicy (14). W konstruowaniu swojego programu charytatywnego Afrahat wykorzystuje jeszcze inne przydatne postacie i wydarzenia biblijne. Broniąc się, Hiob odpiera fałszywe zarzuty o nieczułość wobec potrzebujących (15). Afrahat selekcjonuje teksty zarówno ze Starego Testamentu (historia Abrahama i Lota), jak i z Nowego, komponując tematyczną antologię z wyjaśnieniem idei „ubóstwa duchowego" i ,postawy wobec przybyszów” (16-17). Pers nie pomija ewangelicznej lekcji z bogatym młodzieńcem (18). W ostatnim punkcie De sustentatione egenorum krótko zachęca swoich słuchaczy do kontynuowania pomocy potrzebującym i umacniania już zaangażowanych w to dzieło (19).

\section{Wydania tekstu}

Parisot J., Aphraatis Sapientis Persae Demonstrationes, PSyr 1, Paris 1894, s. 893-930. Wright W., The Homilies of Aphraates, the Persian Sage, edited from syriac manuscripts of the fifth and sixth century in the British Museum, London 1864, s. 357-376 $\left(\lambda s^{x}-u\right)$.

\section{Przekłady nowożytne}

\section{Lacińskie:}

Parisot J., w: Aphraatis Sapientis Persae Demonstrationes, PSyr 1, Paris 1894, s. 894-930.

\section{Francuskie:}

Pierre M.-J., w: Aphraate le Sage Persan, Les Exposés, t. 2: Exposés XI-XXIII, SCh 359, Paris 1989, s. 789-807.

\section{Niemieckie:}

Bruns P., w: Aphrahat, Unterweisungen, Bd. 2, FCh 5/2, Freiburg 1991, s. 460-474. 


\section{Angielskie:}

Letho A., w: The Demonstrations of Aphrahat, the Persian Sage, Gorgias Eastern Christian Studies 27, Piscataway 2010, s. 423-436.

Valanolickal K., w: Aphrahat, Demonstrations II, Moran Etho, Piscataway: Gorgias Press 2011, s. 192-207.

\section{Bibliografia}

Bardy G., Aphraate ou Pharhad, Catholicisme I 686.

Becker A.H., Anti-Judaism and Care of the Poor in Aphrahat's Demonstration 20, JECS 10/3 (2002) s. 305-327.

Becker A.H., Bringing the Heavenly Academy Down to Earth: Approaches to the Imagery of Divine Pedagogy in the East-Syrian Tradition, w: Heavenly Realms and Earthly Realities in Late Antique Religions, red. R.S. Boustan - A. Yoshiko Reed, Cambridge 2004, s. 174 -191.

Bruns P., Das Christusbild Aphrahats des Persischen Weisen, Bonn 1990.

Bruns P., Aphrahat, LThK I 802-803.

Chavanis J.M., Les lettres d'Afrahat, le sage de la Perse, étudiées au point de vue de l'histoire et de la doctrine (Dissertation), Lyon - Saint-Etienne 1908.

Childers J.W., Disciple of Scripture: Character and Exegesis in Aphrahat, w: Exegesis and Hermeneutics in the Churches of the East: Select Papers from the SBL Meeting in San Diego, 2007, ed. V.S. Hovhanessian, New York 2009, s. 23-32.

Childers J.W., Humility Begets Wisdom and Discernment. Character and True Knowledge in Aphrahat's, w: Papers presented at the Fourteenth International Conference on Patristic Studies held in Oxford 2003. Orientalia, Clement, Origen, Athanasius, The Cappadocians, Chrysostom, red. F. Young - M. Edwards - P. Parvis, Studia Patristica 41, Leuven 2006, s. 13-22.

Cody A., When is the Chosen People called a Goy? VT 14 (1964) s. 1-6.

Fiano E., Aphrahat's Christology. A Contextual Reading, Duke University 2010.

Fiano E., Adam and the Logos: Aphrahat's Christology in Demonstration 17 and the „Imponderables of Hellenization”, ZACh 20/3 (2016) s. 437-468.

Grosby S.E., Biblical Ideas of Nationality: Ancient and Modern, Winona Lake 2002.

Hausherr I., Aphraate (Afrahat), DSp I 746-752.

Kessel G.M. - Pinggéra K., A Bibliography of Syriac Ascetic and Mystical Literature, Eastern Christian Studies 11, Leuven - Paris - Walpole 2011.

LaGrand J., The Earliest Christian Mission to ,, all Nations” in the Light of Matthew's Gospel, Cambridge 1995.

Lavenant R., Aphraate (270?-345?), NDPAC I 93-96. 
Lizorkin E., Aphrahat's Demonstrations: A Conversation with the Jews of Mesopotamia, CSCO 642, Subsidia 129, Lovanii 2012.

Maude M., Who were the B'nai Q'yâmâ?, JTS 36 (1935) s. 13-21.

Ortiz de Urbina I., Afraate, LThK I 687.

Parisot J., Aphraates ou Pharhad, DThC I/2 1457-1463.

Parisot J., Praefatio, w: Aphraatis Sapientis Persae Demonstrationes, PSyr 1, Paris 1894, s. IX-LXXX.

Petersen W.L., The Christology of Aphrahat, the Persian Sage: An Excursus on the 17th Demonstration, VigCh 46/3 (1992) s. 241-256.

Petersen W.L., The Peshitta Its Use in Literature and the Liturgy, ed. Bas ter Haar Romeny, Leiden - Boston 2006.

Pierre M.J., Introduction, w: Aphraate le Sage Persan, Les Exposés, t. 1: Exposés I-X, SCh 349, Paris 1988, s. 33-202.

Pierre M.J., Thèmes de la controverse d'Aphraate avec les tendances judaïsantes de son Église, w: Controverses des chrétiens dans l'Iran sassanide (Chrétiens en terre d'Iran II), éd. Ch. Jullien, Cahiers de Studia Iranica 36, Paris 2008, s. 115-128.

Simon M., Verus Israel. Étude sur les relations entre chrétiens et juifs dans l'empire romain (135-425), Paris 1948.

Speiser E.A., People and nation of Israel, JBL 79 (1960) s. 157-163.

Uciecha A., Afrahat, List synodalny (Demonstratio XIV: Exhortatoria. PSyr 1, 573-726), SSHT 46/1 (2013) s. 18-51 (tłumaczenie z języka syryjskiego i komentarz).

Uciecha A., Afrahat. O wierze (Demonstratio Prima. De fide. PSyr 1, 5-45), SSHT 37/2 (2004) s. 158-170 (tłumaczenie z języka syryjskiego, wstęp i komentarz).

Uciecha A., Afrahat. O miłości (Demonstratio Secunda. De caritate. PSyr 1, 48-96), SSHT 39/1 (2006) s. 53-67 (tłumaczenie z języka syryjskiego, wstęp i komentarz).

Uciecha A., Watki polemiczne w pismach Afrahata i świętego Efrema, w: Chrześcijaństwo antyczne, red. J. Drabina, Studia Religiologica 39, ZN UJ 1289, Kraków 2006, s. 113-126.

Uciecha A., Afrahat, O narodach, które zastapity naród (Demonstratio XVI: De Gentibus quae Loco Populi Suffectae Sunt, PSyr 1, 760-784), VoxP 71 (2019) s. 575-591 (tłumaczenie z języka syryjskiego i komentarz).

Uciecha A., Afrahat, O obrzezaniu (Demonstratio XI: De circumcisione, PSyr 1, 467-504), SSHT 48/2 (2015) s. 344-356 (tłumaczenie z języka syryjskiego i komentarz).

Uciecha A., Afrahat, O pasterzach (Demonstratio X: De pastoribus. PSyr 1, 444-465), VoxP 62 (2014), s. 593-602 (tłumaczenie z języka syryjskiego i komentarz).

Uciecha A., Afrahat, O pokarmach czystych i nieczystych (Demonstratio XV: De dictinctione ciborum. Patrologia Syriaca I, 728-757), SSHT 51/2 (2018) s. 345-360 (tłumaczenie z języka syryjskiego i komentarz).

Uciecha A., Afrahat, O pokorze (Demonstratio IX: De humilitate, PSyr 1, 408-441), SSHT 47/2 (2014) s. 256-266 (tłumaczenie z języka syryjskiego i komentarz). 
Uciecha A., Afrahat, O pokutujacych (Demonstratio Septima. De paenitentibus, PSyr 1, 313-360), SSHT 46/1 (2013) s. 5-17 (tłumaczenie z języka syryjskiego i komentarz). Uciecha A., Afrahat. O poście (Demonstratio Tertia. De ieiunio. PSyr 1, 97-136), SSHT 42/1 (2009) s. 85-96 (tłumaczenie z języka syryjskiego, wstęp i komentarz).

Uciecha A., Afrahat, O modlitwie (Demonstratio Quarta. De oratione. PSyr 1, 137-182), SSHT 43/1 (2010) s. 31-44 (tłumaczenie z języka syryjskiego i komentarz).

Uciecha A., Afrahat, O ożywieniu umarlych (Demonstratio VIII: De resurrectione mortuorum, PSyr 1, 361-405), VoxP 61 (2014) s. 503-516 (tłumaczenie z języka syryjskiego i komentarz).

Uciecha A., Afrahat, O wojnach (Demonstratio Quinta. De bellis. PSyr 1, 184-237), SSHT 43/2 (2010) s. 248-262 (thumaczenie z języka syryjskiego i komentarz).

Uciecha A., Afrahat, O synach przymierza (Demonstratio Sexta. De monachis. PSyr 1, 240-312), SSHT 44/1 (2011) s. 177-197 (thumaczenie z języka syryjskiego i komentarz).

Uciecha A., Afrahat, O szabacie (Demonstratio XIII: De sabbato. PSyr 1, 541-572), VoxP 66 (2016) s. 513-526 (thumaczenie z języka syryjskiego i komentarz).

Uciecha A., Afrahat, O śmierci i czasach ostatecznych (Demonstratio XXII: De morte et novissimis temporibus, PSyr 1, 992-1049), VoxP 69 (2018) s. 797-815 (tłumaczenie z języka syryjskiego i komentarz).

Uciecha A., Afrahat, O święcie Paschy (Demonstratio XII: De paschate, PSyr 1, 505-540), SSHT 50/1 (2017) s. 5-18 (thumaczenie z języka syryjskiego i komentarz).

Uciecha A., Afrahat, Przeciw Żydom o dziewictwie i świętości (Demonstratio XVIII: Adversus Iudaeos de virginitate et sanctitate, PSyr 1, 817-844), VoxP 68 (2017) s. 593-604 (tłumaczenie z języka syryjskiego i komentarz).

Uciecha A., Ascetyczna nauka w, Mowach” Afrahata, Studia i Materiały Wydziału Teologicznego Uniwersytetu Śląskiego w Katowicach 3, Katowice 2002.

Uciecha A., Egzegeza biblijna w komentarzach syryjskich Afrahata, Efrema, Iszodada z Merw i Teodora bar Koni. Zarys problematyki, VoxP 67 (2017) s. 673-688.

Uciecha A., Idea walki w ascezie „synów przymierza” na podstawie „Mów” Afrahata, w: Między sensem a bezsensem ludzkiej egzystencji. Teologiczna odpowiedź na fundamentalne pytania współczesnego człowieka. VIII Kongres Teologów Polskich (Poznań 13-16 IX 2010), Poznań 2012, s. 526-535.

Uciecha A., Rola i znaczenie ,córek przymierza” w Kościele Perskim IV i V wieku, VV 19 (2011) s. 233-246.

Uciecha A., Sekrety duchowej walki w mowie „O wojnach” Afrahata, perskiego Mędrca, VoxP 63 (2015) s. 389-396.

Uciecha A., ,, Sen duszy” w pismach Afrahata, VoxP 63 (2015) s. 217-226.

Uciecha A., (tahwaythā) jako metoda egzegetyczna w pismach Afrahata, perskiego Mędrca, BPTh 8/1 (2015) s. 65-80.

Uciecha A., ,, Walka” Zlego z ,, synami przymierza” na podstawie wybranych Mów Afrahata, perskiego Mędrca, VoxP 59 (2013) s. 209-223.

Uciecha A., Wiara w pismach Afrahata, VoxP 61 (2014) s. 479-492. 
Vööbus A., Aphrahat, JbAC 3 (1960) s. 152-155.

Wright W., Apocryphal Acts of Apostles, v. 1: The Syriac Texts, London 1871.

\section{Przeklad ${ }^{18}$}

1 (893, 1-15) Wielki i godny pochwały jest dar, który można znaleźć w człowieku roztropnym, gdy daje ubogim (مسمى) z pracy swoich rąk, a nie $\mathrm{z}$ tego, co ukradł innym, zgodnie z tym, co powiedział Bóg przez proroka: Teraz jest mój odpoczynek! („łwe). Dajcie wytchnąć utrudzonym! Oto ścieżka tego, który słucha! (por. Iz 28,12). Prorok ten mówi jeszcze: Taki jest post miły Panu: łamać swój chleb z głodnym, wprowadzić w twój dom przybysza/tułacza (ruمr), przyodziać nagiego, którego ujrzysz, i nie odwracać się od współziomków (por. Iz 58,6-7). Ten, który tak postępuje, stanie się jak bujny ogród, jak źródło, którego woda nie wyczerpie się (por. Iz 58,11). Jego sprawiedliwość pójdzie przed nim i chwała Pana będzie mu towarzyszyć (por. Iz 58,8) ${ }^{19}$.

2 (893, 16-897, 13) Także Mojżesz ${ }^{20}$, wielki prorok Izraela, napomina

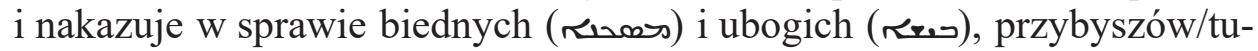

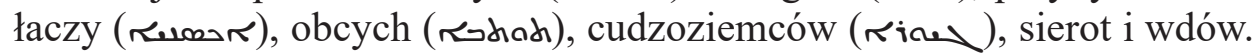
Mówi bowiem do Izraela: W czasie twoich żniw nie ogołocicie waszych pól, nawet jeśli zapomnisz snopka, nie wrócisz się, aby go zabrać, on zostanie dla biednych (rیas), cudzoziemców (rine), sierot i wdów. Pamiętaj, że i ty byłeś takim w Egipcie (por. Pwt 24,19-22; Kpł 19,9-10; 23,22). I dodaje, mówiąc: Gdy będzie winobranie w twojej winnicy, nie wracaj, aby zerwać pozostałe winogrona, i gdy będziesz zbierał twoje oliwki, nie będziesz wracał się ich szukać. Niech zostaną dla cudzoziemców

18 Przekładu dokonano z języka syryjskiego na podstawie wydania krytycznego J.Parisot: Aphraatis Sapientis Persae Demonstrationes, PSyr 1, Paris 1894, s. 893-929.

19 Te same prorockie wezwania Afrahat przywołuje w wykładzie na temat postu De ieiunio: Aphraates, Demonstratio 3, 8, PSyr 1, 113, 17-116, 1: „Kto zatem powstrzymuje się od chleba i wody, i od wszelkiego pokarmu, niech okryje się worem i popiołem, i niech się umartwia; [będzie] kochany, miły i dobry. Jednak o wiele lepiej będzie, gdy uniży samego siebie, rozwiąże więzy nieprawości, rozerwie pęta oszustwa. Wtedy wzejdzie światło jego jak słońce, jego sprawiedliwość będzie kroczyć przed nim; stanie się jak ogród wybujały i jak źródło, którego wody nigdy nie ustają (por. Iz 58,6.8.10.11)". Por. Aphraates, Demonstratio 3: De ieiunio, PSyr 1, 97-136, Afrahat, O poście (Demonstratio tertia. De ieiunio. Patrologia Syriaca I, 97-136), tłumaczenie z języka syryjskiego i komentarz A. Uciecha, SSHT 42/1 (2009) s. 85-96 (tutaj s. 92).

20 W wykładzie Afrahata Mojżesz pełni zadanie prawodawcy i proroka. 


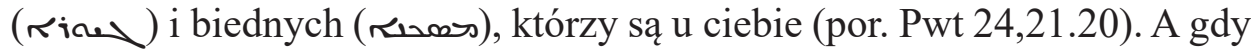
tak uczynisz, Pan, twój Bóg, będzie ci błogosławił we wszystkich dziełach twoich rąk (por. Pwt 24,19). Będziesz jadł [zboże] z dawnych zbiorów, ale kiedy przyjdą nowe zbiory, usuniecie te dawne (por. Kpł 26,10). I mówi im

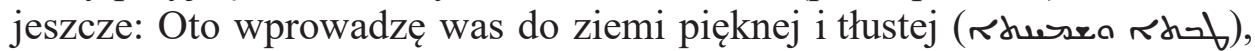
mlekiem i miodem płynącym, do kraju, w którym kamienie mają żelazo, a w górach będziesz wydobywał miedź (por. Pwt 8,7-9), do kraju, na który oczy Pana [są zwrócone] od początku roku aż do końca roku (Pwt 11,12), do kraju, w którym będziesz spożywał chleb bez ograniczeń (Pwt 8,9).

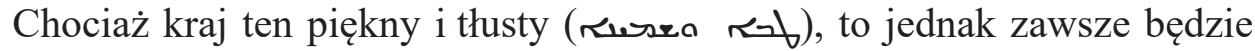
miał biednych (sمصنr). Dlatego On nakazał im znowu, mówiąc: Sześć lat będziesz obsiewał swoją ziemię i zbierał jej płody, ale w siódmym roku

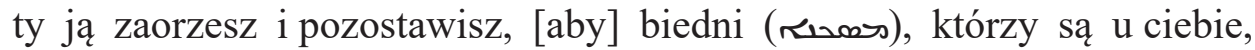
mogli jeść to, co tam się znajdzie, a resztę zjedzą zwierzęta polne (por. Wj 23,10-11). I tak im powiedział: W owym siódmym roku nie będziecie zbierać winogron z latorośli, nie będziecie ścinać tego, co samo wyrosło, lecz zostanie to dla biednych (sمص - por. Kpł 25,4-6). On poznał ich upór i dlatego rzekł: Jeśli wy mówicie: Co będziemy jedli w siódmym roku, gdy się nie sieje ani nie zbiera plonów? On im odrzekł: Ja wam ześlę moje błogosławieństwo w szóstym roku, i ty zbierzesz plon [jakby] z trzech lat: z szóstego, z siódmego i z ósmego. Będziecie jeść płody z szóstego roku aż do dziewiątego roku (por. Kpł 25,20-22).

3 (897, 14-23) Upominał ich z troską: Nie będziesz na noc zostawiał $\mathrm{u}$ siebie zapłaty najemnika, ale wypłacisz mu jego zapłatę w tym samym dniu, aby nie wzywał Boga przeciw tobie i aby grzech nie obciążył ciebie (por. Pwt 24,15). Otóż jeśli zapłata najemnika pozostanie u ciebie przez noc a tej właśnie nocy stracisz życie, biedny (كمصن zostanie pozbawiony swojej zapłaty, która jest u ciebie, i za którą on najął się u ciebie. Albo jeśli to on umrze, wtedy nie znajdziesz nikogo, z kim mógłbyś się rozliczyć i komu zwrócić jego zarobek.

4 (897, 24-900, 24) Również Dawid ${ }^{21}$ troszczył się o biednych (sعą), ubogich ( ( ) , sieroty i wdowy. Ustanowił zarządców nad całym Izraelem,

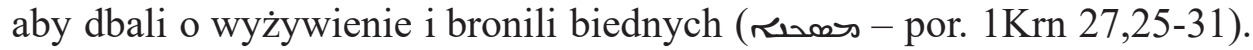

21 Przykład króla Dawida, który troszczył się o biednych zarówno jako sprawiedliwy władca Izraela, jak i jako pobożny autor psalmów. Termin ,jałmużna” (w języku syryjskim וז' ('być sprawiedliwym, prawym'; ‘debitus, iustus, aequus fuit'). Por. Thesaurus Syriacus, t. 1, s. 1083-1084; Lexicon Syriacum, s. 189: „beneficium, eleemosyne”). W myśli Afrahata, inspirowanej teologią skrypturystyczną troska o biednych jest odzwierciedleniem Bożej sprawiedliwości i źródłem szczęścia. 
Śpiewając psalmy i wychwalając swego Boga, zalecił błogosławić tych,

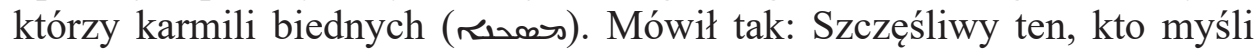
o biednym ( (1 życiu, uczyni szczęśliwym na ziemi i nie wyda go jego przeciwnikom. Gdy zachoruje, pokrzepi go na łożu boleści (por. Ps 41,2-4). W innym psalmie powiedział tak: „Rozdaje i obdarza ubogich (w. - ), jego sprawiedliwość

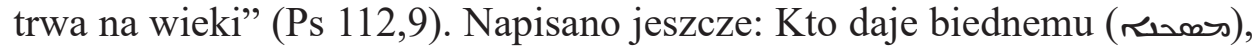
obdarza Boga (por. Prz 28,27; 19,17). I powiedziano: Gromadź jałmużnę i niech stanie się dla ciebie fortuną; ona lepsza jest dla ciebie niż wszystkie skarby (por. Tb 12,8). I napisano: Daj Bogu z tego, co On ci dał (por. Prz 3,9; Tb 4,7). Zobacz (,w)! Ten, który daje jałmużnę ( ₹łası), od potrzebującego (مسمى) otrzymuje; dzięki potrzebującym jego własna bieda zostaje usunięta, gdy on ich wspiera. On mógłby całkowicie usunąć biedę, ale uczynił [z niej] jakby zapłatę biednych (תכ), aby mogła zostać usunięta

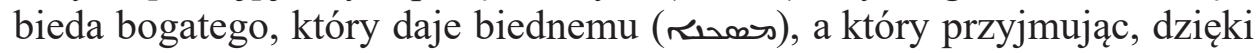
składa Panu za dwóch ${ }^{22}$.

5 (900, 25-904, 2) Nasz Pan Jezus Chrystus, gdy w mowie/przypowie-

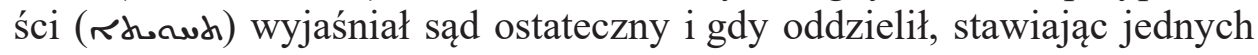
po prawej, a drugich po lewej stronie, pogratulował dobrym, nazywając ich „błogosławionymi swojego Ojca” i „dziedzicami królestwa”, ponie-

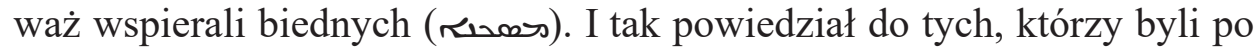
jego prawicy: „Pójdźcie, błogosławieni ojca mojego, weźcie w posiadanie królestwo przygotowane wam od początku! Bo byłem głodny, a daliście mi jeść; byłem spragniony, a daliście mi pić; byłem nagi, a przyodziali-

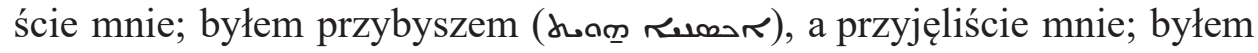
chory, a odwiedziliście mnie; byłem w więzieniu, a przyszliście do mnie" (Mt 25,34-36). Owi sprawiedliwi jednak nie zrozumieli słów naszego Pana i odrzekli, mówiąc: Kiedy to widzieliśmy Cię, Panie, w takiej potrzebie i uczyniliśmy to dla Ciebie? A wtedy On im odpowiedział: „To, co uczyniliście jednemu z tych braci moich najmniejszych, Mnieście uczynili (por. Mt 25,37-40). I zwrócił się i do tych, którzy byli po Jego lewej stronie, mówiąc: Idźcie precz ode Mnie, przeklęci, w ogień przygotowany dla Złego i jego aniołów, ponieważ wszystko to Mnie nie uczyniliście. A wtedy ci z lewej strony odpowiedzą Mu, mówiąc: Panie, kiedy widzieliśmy Cię w takiej [potrzebie], a nie usłużyliśmy Tobie? Odpowie im: To, czego nie

22 Afrahat przybliża istotę i cel posiadania dóbr materialnych. W systemie Bożej ekonomii zbawczej ten, który dzieli się swoim bogactwem z ubogimi, więcej otrzymuje. Obdarowany modli się za bogatego, który pomniejszył swoje dobra materialne, przygotowując w ten sposób miejsce na dobra wieczne. 
uczyniliście tym potrzebującym (oمع), tego Mnie nie uczyniliście (por. Mt 25,41-45). I sprawiedliwi, którzy usłużyli Chrystusowi w potrzebujących (مسمحم), pójdą do życia wiecznego, złoczyńcy zaś odejdą w ogień i w ciemności, ponieważ nie pomogli Chrystusowi w biednych (תمع (ת) (ת) $)^{23}$.

6 (904, 3-12) Mówi jeszcze w innej mowie/przypowieści (rłonod) o bogaczu, który chełpił się swoimi dobrami. Gdy zmagazynował zbiory swojej ziemi, powiedział sobie: Masz wielkie dobra zebrane na długie lata. Mój drogi, odpoczywaj, jedz i używaj! Ale Bóg mu rzekł do niego: Głupcze! ${ }^{24}$ Oto tej nocy upomną się o ciebie. To, co sobie przygotowałeś, komu przypadnie? A potem powiedział: Podobnie dzieje się z tym, który skarby gromadzi dla siebie, a nie jest bogaty u Boga (por. Łk 12,16-21).

7 (904, 13 - 905, 11) I przedstawia jeszcze inną przypowieść o bogaczu, który cieszył się dobrami, a skończył w szeolu. Biedak (sרer), który leżał pod jego drzwiami, pragnął i usilnie błagał, aby zaspokoić głód tym, co spadło ze stołu bogacza (por. Łk 16,19). Powiedziano: Nikt mu niczego nie dał ${ }^{25}$. I jeszcze: „Psy przychodziły i lizały jego rany” (Łk 16,21). Otóż bogacz, który cieszył się dobrami, to naród, który spożywał, tuczył się i buntował, i zapomniał o Panu (por. Pwt 32,15), i który bluźnił Bogu, jak to jest napisane: Synowie Izraela mówili przeciw Bogu i przeciw Mojżeszowi słowami nieprzyzwoitymi (por. Lb 21,5). Mojżesz potraktował ich jako bogaczy i powiedział o nich: Któryż naród ma Boga, który jest tak blisko jak Pan, nasz Bóg, i który ma prawa równie sprawiedliwe i sądy równie uczciwe? (por. Pwt 4,7). I powiedział im jeszcze: Oto wejdziecie do kraju Kanaan, aby go odziedziczyć. Wejdziecie do domów, których nie budowaliście, do winnic i gajów oliwnych, których nie sadziliście, do wykopanych studni, których nie kopaliście. Będziecie spożywać, nasycicie się, i będziecie się rozkoszować, i zapomnicie o Panu (por. Pwt 6,10-12). Tak więc to stali się bogaczami dzięki licznym dobrom, które otrzymali.

8 (905, 12-908, 2) Biedak (كمصنم), który leżał pod drzwiami, to obraz (مhass) naszego Pana ${ }^{26}$, który pragnął i usilnie błagat, aby mu dali owoce, które On mógłby przedstawić Temu, który Go wysłał. Jednak nikt Mu ich nie dał. Powiedziano: „Psy przychodziły i lizały jego rany” (Łk 16,21). Otóż te psy, które przychodziły, to są ludy, które lizały rany naszego Pana;

23 Por. „Szczęśliwy ten, kto myśli o biednym” (Ps 41,2): :

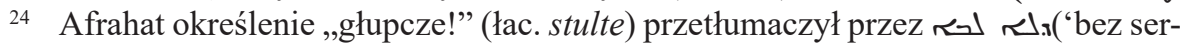

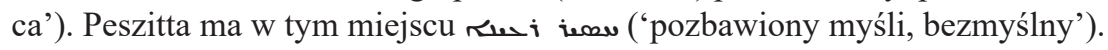

25 Brak tego zdania w wydaniu Peszitty.

26 Przykład chrystologicznej typologii w egzegezie Afrahata: biedak z ewangelicznej przypowieści to symbol Chrystusa. 
[ludy], które biorą Jego ciało i kładą na swoich oczach. Tamci zaś to psy żarłoczne, nienasycone i niezdolne nawet do szczekania (por. Iz 56,10-11). Zobacz (,w) więc, psy, które liżą rany tego biedaka, nie były żarłoczne, ponieważ oni pragną stołu bogacza, a nie lizania ran. To o nich mówił prorok: to psy żarłoczne, nienasycone (por. Iz 56,10). A Dawid powiedział: „Oni będą warczeć jak psy i będą krążyć po mieście” (Ps 59,7).

9 (908, 3-909, 7) Na końcu tej przypowieści powiedziano: Umarł bogacz, został pogrzebany i skazany na męki. Umarł również ten biedak

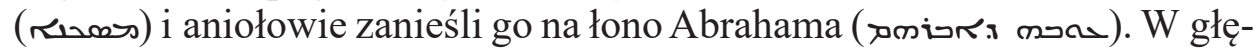
bi szeolu i na mękach bogacz podniósł oczy i zobaczył Abrahama i Łazarza na jego łonie (حصحس)). I zawołał donośnym głosem: Ojcze Abrahamie, miej litość nade mną, wyślij Łazarza. Niech przyjdzie mi z pomocą i ochłodzi mój język w tym skwarze, w którym tak okropnie cierpię. Abraham mu odrzekł: Mój synu, wspomnij, że za życia otrzymałeś swoje dobra, Łazarz zaś niedolę. Dzisiaj to ty upominasz się, a on nie przyjdzie ci z pomocą, gdyż jest ogromna przepaść między wami a nami i nie można przejść od was do nas, ani od nas do was. On mu odparł: Proszę cię więc, mój ojcze, poślij go do domu mojego ojca, ponieważ mam pięciu braci: niech ich ostrzeże (smo), aby i oni nie grzeszyli i nie przyszli na to miejsce męki (rowed). Abraham mu rzekł: Mają Mojżesza i proroków, niech ich słuchają! On odpowiedział: Nie, ojcze Abrahamie, lecz gdyby ktoś z umarłych udał się do nich, to się nawrócą. Abraham mu odparł: Jeśli nie słuchają ani Mojżesza, ani proroków, to choćby ktoś z umarłych udał się do nich, nie uwierzą mu (por. Łk 16,22-31). Jak to ci już powiedziałem, bogacz to naród, a biedak (s (s ) to nasz Pan, według tego, co napisano: Pan zechciał go poniżyć i obarczyć cierpieniem (por. Iz 53,10). A Apostoł mówi: To dla was bogaty stał się ubogim, abyście stali się bogatymi dzięki Jego ubóstwu (por. 2Kor 8,9). I jeszcze powiedział: Uniżył samego siebie, stawszy się posłusznym aż do śmierci, [i to] śmierci krzyżowej (por. Flp 2,8).

10 (909, 8-18) Gdy powiedziano: I umarł ten bogacz, w rzeczywistości prorok mówi o nich: Pan Bóg cię zabije! I nada inne imię swoim sługom (por. Iz 65,15). Jego słudzy bowiem to naród, który pochodzi z ludów. Gdy nadał im inne imię, to nazwał ich „chrześcijanami”, czyli „mesjaszami”, ale nie ,wodzami Sodomy i ludem Gomory” (por. Iz 1,10), jak [nazwał bogaczy]. Tak nam oświadcza „Nauczanie (مłaı๐i) dwunastu Apostołów”: „W Antiochii też po raz pierwszy nazwano uczniów chrześcijanami” (Dz 11,26).

11 (909, 19-912, 10) Umarł również ten biedak (sحa) i aniołowie

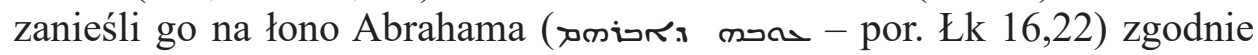


z tym, co rzekła Maria: „Zabrali Pana mego i nie wiem, gdzie Go położyli” (J 20,13). Ci właśnie aniołowie powiedzieli do Marii: On zmartwychwstał i odszedł do Tego, który Go posłał (por. Mt 28,6; J 16,5). To właśnie ci aniołowie usługiwali mu, jak to wcześniej powiedziano w Ewangelii: Oto aniołowie zstąpili i usługiwali Jezusowi (por. Mt 4,11). Także przy Jego narodzeniu ci aniołowie oddali chwałę, mówiąc: Chwała Bogu na wysokościach a ludziom dobra nowina (סحَّ - por. Łk 2,14). To archanioł Gabriel zwiastował nowinę (סح) o narodzinach. On sam powiedział do swojego ucznia Szymona: Czy myślisz, że nie mógłbym poprosić Ojca mojego, aby Mi dał armię zastępów aniołów? (por. Mt 26,53). I powiedział jeszcze do swoich uczniów: „Ujrzycie niebiosa otwarte i aniołów Bożych wstępujących i zstępujących na Syna Człowieczego" (J 1,51).

$12(912,11-913,5)$ Napisałem ci o tym wszystkim, ponieważ napisano: Umarł również ten Biedak (sمer) i aniołowie zanieśli go na łono Abrahama (حחכת - pris - por. Łk 16,22). Gdy powiedziano, że go za-

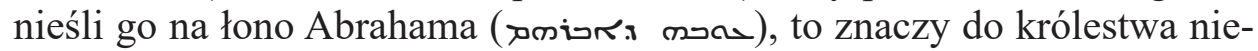
bieskiego, a gdy Abraham powiedział do bogacza: Jest ogromna przepaść między nami a wami i nikt nie może przejść od was do nas, ani od nas do was (por. Łk 16,26), to znaczy, że po śmierci i po zmartwychwstaniu nawrócenie nie jest już możliwe: bezbożni nie mogą się już więcej nawrócić, by wejść do królestwa, a sprawiedliwi nie moga już zgrzeszyć i iść

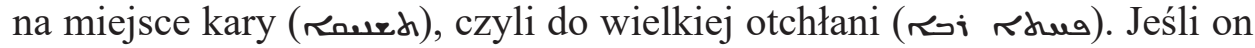
prosił go [Abrahama] o pomoc, ale nikogo nie wysłano na ratunek, to znaczy, że w owym dniu nikt już nie będzie mógł pomóc swojemu bliskiemu. Gdy powiedział: Poślij go do domu mojego ojca, niech ich ostrzeże (smo), aby nie grzeszyli, oraz gdy mu odpowiedział: Mają Mojżesza i proroków, niech ich słuchają! A on na to: Gdyby ktoś z umarłych udał się do nich, to się nawrócą (por. Łk 16,27-30), to widać wyraźnie, że chodzi o ten naród, który nie słuchał Mojżesza oraz proroków i który nie uwierzył Jezusowi, który powstał z martwych ${ }^{27}$.

13 (913, 6-14) Napisano jeszcze o grzeszniku, że jego winy zostaną wymazane dzięki jałmużnom ( rło.s), jak to powiedział Daniel do

27 Zagadnienie odrzucenia i substytucji narodu wybranego na korzyść nowego ludu. Por. Aphraates, Demonstratio 16, Afrahat, $O$ narodach, które zastapity naród (Demonstratio XVI: De Gentibus quae Loco Populi Suffectae Sunt, PSyr 1, 760-784), tłumaczenie z języka syryjskiego i komentarz A. Uciecha, VoxP 71 (2019) s. 575-591; Aphraates, Demonstratio 15, A. Uciecha, Afrahat, O pokarmach czystych i nieczystych (Demonstratio XV: De distinctione ciborum, PSyr 1, 728-757), SSHT 51/2 (2018) s. 345-360 (tłumaczenie z języka syryjskiego i komentarz). 
Nabuchodonozora: Okup swe grzechy jałmużnami (rłorı), a swoją nieprawość miłosierdziem nad ubogimi (por. Dn 4,24). Prorok zaś tak powiedział do synów Izraela: Deptaliście biednego (sصes) i braliście od niego łapówki, i dlatego nie będziecie mieszkali w domach z kamienia ciosanego, które zbudowaliście sobie, i nie będziecie pili wina z pięknych winnic, które zasadziliście (por. Am 5,11) ${ }^{28}$.

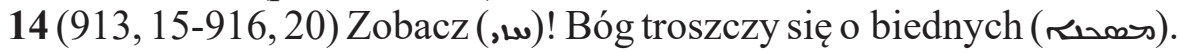

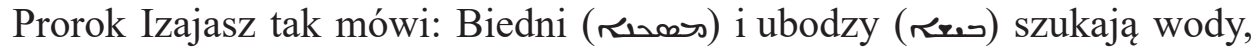
a jej nie ma! Ich język wysechł już z pragnienia. Ja, Pan, Bóg Izraela, wysłucham ich i nie opuszczę ich. Aby ich język nie wysychał z braku wody, wzbudzę rzeki w górach i źródła w głębi dolin. Na pustyni zasadzę cedry, akacje, mirty i oliwki; w dolinie umieszczę wspaniałe cyprysy, wszystkie

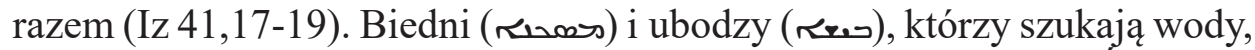
a jej nie ma, to lud, który pochodzi z ludów, woda zaś to nauka Świętych Pism: jeśli ich język jest suchy, to znaczy [suchy] w uwielbienie. Gdy mówi, że wzbudzi rzeki w górach i źródła w głębi dolin, to znaczy, góry i doliny to są ludzie wysoko postawieni i pokorni, z których wypłyną rzeki i źródła. Powiedział: Na pustyni zasadzę cedry, akacje, mirty i oliwki, w dolinie umieszczę wspaniałe cyprysy. W rzeczywistości pustynia to są ludy, które dawniej były jak pustynia. Cedry, akacje, mirty i oliwki, to są kapłani ludu

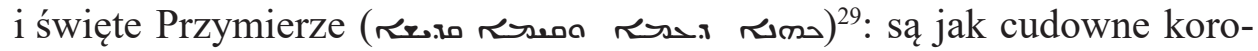
ny drzew, których listowie i zimą, i latem jest świeże i bujne. W dolinie umieszczę wspaniałe cyprysy, wszystkie razem: to znaczy z pokornych lu-

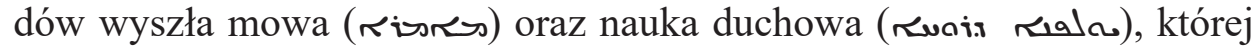
woń jest miła jak woń cyprysu, jak to powiedział Apostoł: Po wszystkich miejscach jesteśmy miłą Bogu wonnością (por. 2Kor 2,14-15).

$15(916,21-917,21)$ Do Hioba mówili jego przyjaciele, aby go znieważyć w czasie jego próby: Jak coś takiego mogło ci się zdarzyć? Czy może odesłałeś wdowę z pustymi rękami i poniżyłeś ramię sieroty? ${ }^{30} \mathrm{Czy}$ może odmówiłeś wody spragnionym i nie dałeś chleba głodnemu? Czy wziąłeś zapłatę sierocie? Czy wziąłeś w zastaw wołu wdowy? Ktoś obsiał swoją ziemię, a jakiś gwałtowny właściciel zabrał mu ją: ale to ty uczyniłeś

28 Jałmużna jako „okup za grzechy”. Izraelici odrzucili możliwość nawrócenia i dlatego utracili obietnice zawarte w Bożym przymierzu.

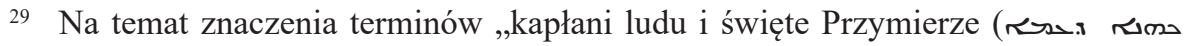
م. (PSyr 1, 916, 12-13), por. A. Uciecha, Ascetyczna nauka w ,Mowach” Afrahata, Studia i Materiały Wydziału Teologicznego Uniwersytetu Śląskiego w Katowicach 3, Katowice 2002, s. 38.

30 Por. Hi 22,9: „miażdżysz ramiona sierotom” (BT). 
to wszystko i dlatego wokół ciebie są pułapki i przeraża cię nagły strach (por. Hi 22,6-10; 24,3). Gdy tego wysłuchał, odpowiedział na swoją obronę i tak im rzekł: Niewidomemu byłem oczami, chromemu służyłem za nogi (por. Hi 29,15). Ci, którzy nie mieli odzienia, mogli ogrzać się wełną mych owiec. Nie podniosłem ręki przeciw sierocie, a gdy stanął $w$ drzwiach, pospieszyłem z pomocą (por. Hi 31,19-21). Nie odprawiłem wdowy z pustymi rękami i swego chleba nie spożywałem sam, ale jadł go ze mną sierota (por. Hi 31,16-17). Rozbijałem szczękę łotrowi i wydzierałem mu łupy z zębów, i mówiłem: uratuję biednego (مسمص - por. Hi 29,17). I mówił jeszcze: Podróżnemu otwierałem podwoje i nie pozwoliłem zagasnąć oczom wdowy (por. Hi 31,32.16). Jeśli nie czyniłem tego wszystkiego, niech bark mi wyskoczy ze stawu i moje ramię złamie się w łokciu! (por. Hi 31,22). Zlitujcie się nade mną, zlitujcie się, wy, moi przyjaciele, ponieważ Bóg dotknął mnie swą ręką (por. Hi 19,21), a to wszystko przyszło na mnie nie przez moje grzechy.

16 (917, 22-921, 12) Specjalnie na temat biednych (sمصح) nasz Pan podał ostrzeżenie, gdy mówił do pana uczty: Gdy wydajesz obiad albo wieczerzę, nie zapraszaj swoich przyjaciół ani braci, ani zamożnych sąsiadów, ani tych, którzy ciebie zaproszą, ponieważ miałbyś tam swoją odpłatę. Lecz kiedy to czynisz [urządzasz przyjęcie], zaproś ubogich i prostych (ش szczęśliwy, ponieważ nie mają czym tobie się odwdzięczyć; odpłatę bowiem otrzymasz przy zmartwychwstaniu ze sprawiedliwymi (por. Łk 14,12-14). I powiedział jeszcze: Czyńcie sobie przyjaciół (nswi) ${ }^{31}$ niegodziwą mamoną, aby gdy się skończy, oni przyjęli was do wiecznych przy-

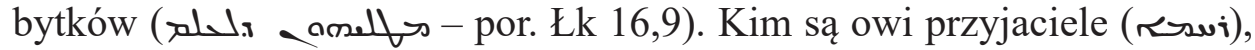
dla których są wieczne przybytki (sلą), które ludzie mogą zdobyć niegodziwą mamoną? Otóż tymi przyjaciółmi jest (هیwi) Bóg i Jego Pomazaniec, których są wieczne przybytki (هلهم). Gdy ktoś daje biednym z tego, co posiada, wypełnia dobrą wolę Boga i Jego Pomazańca, zgodnie z tym, co powiedziano: Oto mój odpoczynek! Dajcie odpoczynek strudzonym (por. Iz 28,12). Nasz Pan powiedział: To, co uczyniliście dla nich, Mnieście uczynili (por. Mt 25,40). Powiedziano: Czyńcie sobie przyjaciół, według tego, co rzekł Izajasz: Nie lękaj się, Jakubie, mój sługo, potomstwo Abrahama, mojego przyjaciela (swi-Iz 41,10.8; 44,2). Nasz Pan powiedział do swoich uczniów: Nazwałem was swoimi przyjaciółmi (i),

31 Afrahat zwraca się do słuchacza za pomocą wyrażenia „mój przyjacielu” (טרחת) będącego konwencją literacką, w tekście biblijnym zaś zachowuje formę „przyjaciel (rsui)". 
ponieważ oznajmiłem wam wszystko, co usłyszałem od mojego Ojca, (por. J 15,15). To właśnie są przyjaciele (

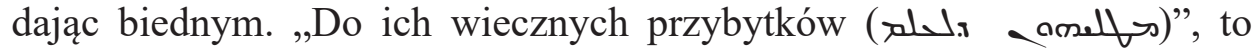
znaczy tam, gdzie odpoczywają sprawiedliwi, dom zamieszkania nie ręką uczyniony, który nie jest częścią stworzenia, jak powiedział Apostoł. Nasz

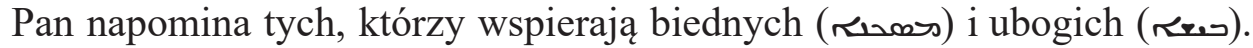
Tak mówi: Co do was, to nie czyńcie sobie skarbu na ziemi, gdzie złodzieje włamują się i kradną i gdzie mól atakuje i niszczy. Ale czyńcie sobie skarb w niebie, taki skarb, który nie zawodzi, tam, gdzie mól nie niszczy i złodzieje nie kradną; tam, gdzie będzie wasz skarb, tam będzie i wasze serce (por. Mt 6,19-21; Łk 12,33-34). Apostoł powiedział jeszcze o apostołach, którzy go poprzedzili: Polecili nam jedynie to, abyśmy pamiętali o bied-

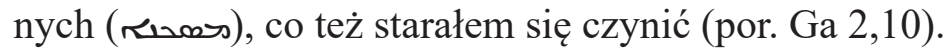

17 (921, 13-928, 4) Nasz Pan rzekł: Błogosławieni ubodzy w duchu

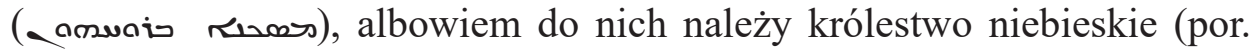
Mt 5,3), i powiedział o bogatych: Biada wam, bogaczom, bo otrzymaliście to, czego żądaliście (por. Łk 6,24). Kim są ci bogacze, którzy otrzymali to, czego żądali? To właśnie ten naród, który nas poprzedzał. Oni żądali wszystkiego tego, co jest ziemskie, ale nie, co jest niebieskie, jak ten bogacz, który zebrał i pomnożył zbiory, ale nie był bogaty przed Bogiem (por. $Ł k$ 12,21). I jak ten, który cieszył się bogactwem: otrzymał to, czego żądał za życia, a w zaświatach już nie otrzymał tego, czego żądał (por. Łk 16,25). Powiedział [nasz Pan] o ubogich (תمصن/): Królestwo niebieskie do nich należy (por. Mt 5,3). Czy moglibyśmy powiedzieć, że mówi tutaj o ubogich w dobra ziemskie? Otóż są ubodzy, którzy nic nie posiadają i którzy są złodziejami, zabójcami, kłamcami, podżegaczami do zbrodni, wyjętymi spod prawa. Czyż królestwo niebieskie byłoby dla nich? Nie daj Boże! Ale błogosławieństwo jest dane ubogim w duchu, tym, którzy boją się Boga, a których dobra nie liczą się ze względu na bojaźń Bożą, lecz którzy ich używają jako coś niekoniecznego. Bogaty Abraham, który okazał się ubogi przed Bogiem, Izaak i Jakub, synowie obietnicy, którzy kroczyli jego ścieżkami, błagali Boga, chociaż byli bogaci. Hiob, najbogatszy spośród synów Orientu (por. Hi 1,3), gdy został doświadczony w swoich synach i w swoich dobrach, kochał swego Boga, który mu je dał (por. Hi 1,22) i nie przeklinał Boga. Oto są ci, o których mówi Apostoł: Dzięki miłości wobec przybyszów (محمسك)) otrzymali życie, oni bowiem przyjęli aniołów (por. Hbr 13,2). Kim są owi przyjaciele przybyszów (محمس)), jeśli nie Abraham, Lot, Hiob i inni sprawiedliwi, którzy są im podobni? Zobacz (,w), mój przyjacielu (טרברת), jak ci ojcowie miłowali przybyszów (محمعسم): 
Gdy Abraham dostrzegł tych aniołów, wziął ich za przybyszów ( wyszedł im na spotkanie i pokłonił się przed nimi (por. Rdz 18,2), aby weszli do jego namiotu i odpoczęli u niego. Tak że został błogosławiony jako gospodarz dzięki swojej miłości do przybyszów (محمیr). To właśnie jest wspaniałe: ten wielki człowiek uniżony i oddający pokłon, błagający i proszący usilnie przybyszów (rم), aby weszli do niego i odpoczęli. Otóż w zwyczaju Abrahama było zawsze przyjmować u siebie przybyszów

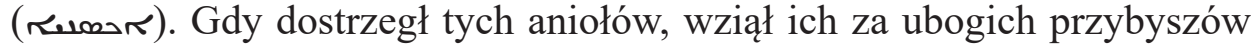
(م) i i wyszedł im na spotkanie, aby ich przyjąć jako gości, podczas gdy ich [prawdziwe] dostojeństwo było zasłonięte przed jego oczami. On wstał przed nimi, aby im służyć. Kazał Sarze, aby własnymi rękami zaczyniła ciasto z trzech korców pszennej mąki, z pewnością jeden korzec na każdego mężczyznę. I według tej miary natłoczonej (por. Łk 6,38) on otrzymałby swoją odpłatę stosownie do niej. Dzięki miłości wobec przybyszów (r) otrzymał jako wynagrodzenie obietnicę, którą w jego potomstwie będą sobie błogosławić wszystkie narody (por. Rdz 12,3; 18,18). Podobnie było z Lotem: przyjął przybyszów (محمسك), a [Bóg] uchronił go w Sodomie (por. Rdz 19,1-22), która nienawidziła przybyszów (r אحمع), jak to powiedział Ezechiel: Oto taka była wina Sodomy i jej towarzyszek: nie wspierały biednego i nieszczęśliwego. Widząc to, zniszczyłem je (por. Ez 16,49-50). Również Zacheusz, gdy nasz Pan wszedł do niego, powiedział: Oto połowę mojego majątku daję ubogim, a temu, kogo skrzywdziłem, oddaję poczwórnie. Nasz Pan mu rzekł: Dzisiaj życie [wróciło do] tego domu (por. Łk 19,8-9).

18 (928, 5-27) I jeszcze ten bogacz, który przyszedł do naszego Pana i powiedział mu: Co mam czynić, aby posiąść życie wieczne? Nasz Pan mu rzekł: Nie cudzołóż, nie kradnij, czcij swego ojca i matkę, kochaj swego bliźniego jak siebie samego. On Mu rzekł: Wszystkiego tego przestrzegałem od

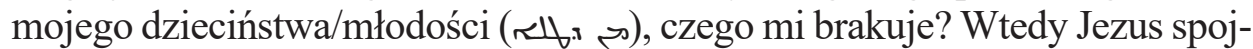
rzał na niego z miłością i rzekł mu: Jednego ci brakuje: Jeśli chcesz osiągnąć doskonałość, idź, sprzedaj wszystko, co masz, i rozdaj biednym (sمصنr), weź swój krzyż i chodź za Mną! Gdy młodzieniec to usłyszał, mocno się zasmucił i wrócił do siebie ponury, gdyż był bardzo bogaty. Jezus zaś powiedział: Zobaczcie (aw)! Jak trudno jest tym, którzy w dobrach pokładają nadzieję, wejść do królestwa Bożego. I dodał: Łatwiej jest wielbłądowi przejść przez ucho igielne, niż bogatemu [wejść] do królestwa Bożego (por. Mt 19,16-24; Mk 10,17-25; Łk 18,18-25). Także Apostoł mówi: w zasiewie kto skąpo sieje, ten skąpo i zbiera (por. 2Kor 9,6), kto zaś hojnie sieje, ten hojnie też zbierać będzie. Gdy czynimy dobro, nie męczymy się (por. Ga 6,9). 
19 (929, 1-10) Napisałem Ci, mój przyjacielu (טרصحת), to krótkie we-

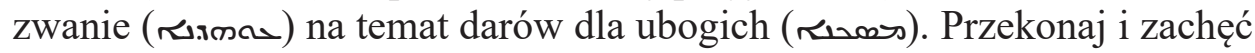
tych, którzy dają, aby rozsiewali przed sobą zasiew życia, zgodnie z tym, co jest napisane: Ucz prawego, a zwiększy swą wiedzę (por. Prz 9,9). Wszystkich, którzy miłują ubogich (rیas), zachęcaj tym wezwaniem (حسח (حח), abyś i ty miał udział w ich trudzie ${ }^{32}$.

Koniec Mowy O trosce o biednych.

Z języka syryjskiego przełożył wstępem i komentarzem opatrzył ks. Andrzej Uciecha ${ }^{33}$

32 Podobnie jak w Adversus Iudaeos motywy podjęcia tematu zostały wyjaśnione pod koniec mowy: „Napisałem Ci te kilka argumentów przekonujących, abyś mógł odpowiedzieć, gdy będziesz musiał dać odpowiedź, i abyś potwierdził słowa twojego słuchacza, i aby on nie uległ ich kłótliwemu dowodzeniu. Oni bowiem nie przyjmują argumentów, ponieważ Pismo zostało zamknięte dla nich, aby nie rozumieli i nie mogli pojąć tego, że Bóg jest miłosierny dla wszystkich. Tak powiedziano o nich: Ten lud sławi mnie wargami, ale jego serce jest daleko ode mnie (por. Iz 29,13; Mt 15,8). A oni mówili do Jeremiasza: Nie posłuchamy twojego słowa, które ty nam mówisz w imię Pana (por. Jr 44,16)" (Aphraates, Demonstratio 19, 12, PSyr 1, 885, 26-888, 11). Podobny zabieg przypomnienia motywacji na koniec wykładu występuje w De Christo Dei Filio:

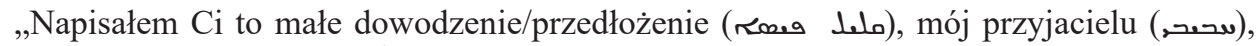
abyś mógł odpowiedzieć Żydom, ponieważ oni mówią, że Bóg nie ma syna, i ponieważ my nazywamy Go Bogiem i Synem Bożym, Królem i Pierworodnym wszelkiego stworzenia" (Aphraates, Demonstratio 17, 12, PSyr 1, 816, 1-7; w De distinctione ciborum, Aphraates, Demonstratio 15, 9, PSyr 1, 757, 12-23).

33 Ks. dr hab. Andrzej Uciecha, prof. UŚ na Wydziale Teologicznym Uniwersytetu Śląskiegow Katowicach; e-mail: andrzej.uciecha@wp.pl; ORCID: 0000-0003-2507-8544. 